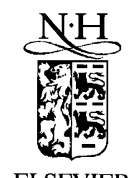

ELSEVIER

\title{
Discretionary reductions in warrant exercise prices ${ }^{\text {ts }}$
}

\author{
John S. Howe ${ }^{\mathrm{a}, *}$, Tie $\mathrm{Su}^{\mathrm{b}}$ \\ ${ }^{a}$ Department of Finance, College of Business, University of Missouri-Columbia, \\ Columbia, MO 65211-6100, USA \\ ${ }^{\mathrm{b}}$ Department of Finance, University of Miami, Coral Gables, FL 33124, USA
}

Received 11 January 2000; accepted 21 March 2001

\begin{abstract}
Managers can decide to reduce a warrant's exercise price. A reduction in exercise price can induce exercise (a conversion-forcing reduction) or not (a long-term reduction). Conversion-forcing firms show an abnormal return of $-1.53 \%$ on the announcement day but they perform well over the three years following the announcement. This finding suggests that the funds raised from warrant exercise are invested in profitable projects. Long-term reductions show an abnormal return of $-1.15 \%$ on the announcement day. These firms also perform well following the reduction, which suggests that the lower exercise price restores managerial incentives. (C) 2001 Elsevier Science S.A. All rights reserved.
\end{abstract}

JEL classfication: $\mathrm{G} 32$

Keywords: Warrants; Equity financing; Exercise price; Managerial flexibility; Security design

\footnotetext{
is The first author acknowledges financial support from the University of Missouri Research Board and the College of Business at the University of Missouri. The second author acknowledges financial support from the School of Business, University of Miami. The authors are appreciative for the valuable suggestions of an anonymous referee and the useful comments of G. William Schwert (the editor). We also note the exemplary computing support of Ron Howren and Murali Jagannathan, and the helpful comments of Chris Anderson, Tim Burch, Doug Emery, Pat Fishe, Larry Goldberg, Andrea Heuson, and Mitchell Petersen. Thanks also to Yongyong Mu for data collection.

*Corresponding author.

E-mail address: howej@missouri.edu (J.S. Howe).
} 
Barringer Resources Inc. said it reduced the exercise price on its class $B$ warrants to $\$ 2.25$ from $\$ 4.03$, effective today, for the next 30 days. On March 13 the exercise price will revert back to \$4.03.

-Dow Jones News Retrieval, February 11, 1991, 10:42 a.m.

\section{Introduction}

The finance profession has taken an increased interest in the characteristics of securities issued by corporations, and in the logic underlying the choice of characteristics. For example, Barclay and Smith (1995a) and Guedes and Opler (1996) address the maturity of debt issues; Barclay and Smith (1995b) study the priority structure of debt; Johnson (1997) investigates the choice between private and public debt; Carey et al. (1998) analyze the distinction between lending by banks and lending by finance companies; and Mayers (1998) and Stein (1992) examine the rationale for using convertible debt. Anderson (1999) examines the provisions in Brazilian bond indentures.

Warrant agreements, which are analogous to bond indentures, often contain option-like provisions that increase managers' control over financial decisions. Several of these provisions have been studied in the literature. Callability at a nominal price is one feature, and typically is used to force conversion. Schultz (1993b) empirically examines conversion-forcing calls of warrants and concludes that warrants are called optimally. He reports a 3\% decline in stock price in response to the call announcement. Extendability is another option-like warrant characteristic. Extendability allows managers to extend the life of a warrant issue. Howe and Wei (1993) report that warrants increase in value in response to extension announcements, and that stock prices also respond positively to such announcements.

We examine another common feature of warrant agreements, which is managerial discretion to reduce the warrant exercise price. Practitioners sometimes refer to this as "sweetening the warrant". Reductions in the warrant exercise price can be temporary, as in the Barringer Resources case cited at the beginning of the paper, or they can be permanent. For example:

American Complex Care Inc. Friday announced that its board of directors has unanimously approved a reduction in the exercise price of the company's publicly traded common stock purchase warrant to $\$ 2.25$ per share. ... The previous exercise price was $\$ 5.00$ per share.

Temporary reductions almost always involve warrants that are out of the money before the exercise price reduction and in the money at the new exercise price. Temporary reductions are also conversion forcing. That is, the warrants' intrinsic value at the temporarily lower exercise price exceeds their ongoing 
value at the soon-to-be-reinstated (old) exercise price, and rational investors will exercise their warrants before the exercise price reverts to its former level. We provide evidence to support the assertion that the temporary reductions in this study are conversion forcing.

No stock in our sample is paying a dividend at the time of the announcement of the warrant exercise price reduction. Therefore, the permanent reductions do not appear to force conversion because, in the absence of a dividend payment, it is not optimal to exercise the warrant prior to its expiration. However, some of the permanent reductions take place near the end of the life of the warrant. As with the temporary reductions, these events almost always involve warrants that are out of the money prior to the reduction in exercise price and in the money afterwards. We classify a permanent reduction as conversion forcing if it takes place within 60 days of the warrant's expiration date, a period that closely corresponds to the time it takes for a firm to prepare for a new stock offering (Wall Street Journal, June 20, 2000, p. C1).

Thus, we categorize warrant exercise price reductions by two distinct types: conversion-forcing and long-term. The distinction is important, because a conversion-forcing reduction results in a more or less immediate equity issue, but a long-term reduction does not. A long-term reduction is a revision in the terms of a financial contract. The motivations for the two events can be very different.

Our empirical investigation examines both the warrant and stock price reactions to the announcement of a reduction of the warrant exercise price. We examine the reactions for both the conversion-forcing and long-term samples. We then explain the cross-sectional variation in the stock price reaction to warrant exercise price reductions. As suggested by an agency-cost explanation for the issuance of warrants, we document the failure rates and long-run performance of the conversion-forcing firms to determine whether firms squander the funds raised from warrant exercise. To test the conjecture that the new exercise price restores managerial incentives to seek out profitable projects, we also examine the failure rates and long-run performance of the long-term sample.

We perform our research for several reasons. First, for conversion-forcing firms, the decision to reduce the exercise price of a warrant is a financing decision that has not been examined in the literature. Characteristics of conversion-forcing firms suggest that they would have difficulty in accessing the capital markets directly. For example, they are small and thus face high transaction costs for a conventional equity offering. The median amount of capital raised by warrant exercise for our conversion-forcing sample is $\$ 1.89$ million. The data in Smith (1977, Table 1) suggest that as a percentage of proceeds, the costs of flotation would be $15.29 \%$ for an underwritten equity offering of this size. These firms are also young, derive much of their value from growth opportunities, and have poor operating performance. The option 
to reduce the exercise price of an issue of warrants allows the firms to raise capital without facing additional direct monitoring by capital providers (Easterbrook, 1984). The market reaction to the reduction speaks to the efficacy of this feature of the warrant agreement.

Second, Schultz (1993a) argues that warrants are part of a staged financing process that reduces agency costs associated with free cash flow (Jensen, 1986). This process is analogous to sequential financing by venture capital firms (see, e.g., Sahlman, 1990). The option to accelerate the sale of new shares by reducing the exercise price, which occurs in the conversion-forcing sample, might compromise the efficacy of warrants in controlling agency costs. Our evidence suggests that the benefits of managerial flexibility outweigh concerns about the agency costs of free cash flows associated with conversion-forcing reductions in exercise price. Kahan and Yermack (1998) provide similar evidence about bond covenants.

Third, we perceive the long-term reductions as the rewriting of a financial contract, and we see the option to reduce the exercise price as a low-cost opportunity to rewrite the warrant contract. As we show below, the long-term reductions involve warrants that are typically well out of the money. We conjecture that the incentives of the warrant contract are significantly diminished when a warrant is substantially out of the money. Schultz (1993a) shows that warrant exercise is a second-stage financing event. If the warrant is well out of the money, the managers might not believe they can find enough profitable projects to drive the stock price above the (old) exercise price and thus bring about the second stage of financing. Rewriting the contract could restore their incentive to seek out profitable investments. Other researchers use a similar argument to justify the "repricing" of executive stock options (e.g., Acharya et al., 2000).

Our evidence suggests that giving management the discretion to reduce the exercise price is an efficient provision of the warrant agreement. Our evidence takes several forms. First, the average abnormal return on the announcement day is $-1.53 \%$ for conversion-forcing reductions. For the long-term reductions, the average stock price reaction to the announcement is $-1.15 \%$. Second, there is a marginally positive stock price reaction to announcements that provide information about management's plans for the use of the proceeds that result from warrant exercise (all of these announcements come from the conversion-forcing sample). Third, the conversion-forcing firms do not fail at a higher rate than do a sample of control firms. Fourth, firms that announce a long-term reduction in the warrant exercise price significantly outperform their controls over the three-year period following the announcement.

Overall our evidence suggests no material conflicts between shareholders and warrantholders, and that the costs of potential shareholder/manager agency conflict are outweighed by the benefits of managerial flexibility. 
In Section 2 we describe our empirical tests. Section 3 describes the data and method of analysis. Section 4 contains our initial findings. In Section 5 we report our correlation and regression results. We examine the long-run viability of the firms in Section 6. Section 7 summarizes and concludes.

\section{Empirical tests}

Our first empirical tests focus on the price reaction of a firm's warrants to an announcement of a reduction of the exercise price. The announcements are anticipated because the option to reduce the exercise price is explicit in the warrant agreement. The exercise price reduction announcement resolves investors' uncertainty about whether there might be an exercise price reduction and what the new exercise price will be. Reducing the exercise price will increase warrant value, all else equal. Therefore, we expect the warrants for both the conversion-forcing and long-term firms to increase in value at the announcement.

Our second test examines the stock price reaction to the announcement for conversion-forcing reductions. In a perfect market, firm value is unaffected by financing decisions, holding the investment decision constant, and the total market value of claims on the firm remains unchanged. If we assume no change in the value of debt claims on the firm, then as the warrants increase in value, the common stock declines in value, and the announcement of a reduction in exercise price results in a wealth transfer from shareholders to warrantholders.

If markets are imperfect, there will be at least two other factors that influence the stock price at the time of the announcement. The first is a saving of out-ofpocket transaction costs relative to the cost of an underwritten equity offering. The cost of raising equity capital through a reduction in warrant exercise price could be similar to that of a rights offering. (The marginal cost is likely to be less than that of a rights offering because the warrants already have been issued.) Smith (1977) shows that rights offerings involve considerably lower out-of-pocket costs than underwritten offerings. The saving in transaction costs should exert a positive influence on stock price.

The second factor is the well documented "SEO effect," the negative reaction to announcements of seasoned equity issues, perhaps because such announcements signal negative information (see, e.g., Myers and Majluf, 1984). The SEO effect will cause a decline in stock price on the announcement date, ceteris paribus.

The observed stock price reaction for the conversion-forcing sample represents the net effect of the wealth transfer, the savings in transaction costs, and the SEO effect. Therefore, the stock price reaction could be negative, zero, or positive. 
Our third test examines the stock price reaction to the announcement of a long-term exercise price reduction. As with a conversion-forcing reduction, a long-term reduction results in a wealth transfer from shareholders to warrantholders. All else equal, we expect a negative stock price reaction. However, in an imperfect market, such an announcement could contain information. For example, a long-term reduction in exercise price is an admission that there is little chance that the stock price will exceed the old exercise price. Because the decision is made by (presumably well-informed) firm managers, the market will infer bad news from the announcement. The signaling effect would then augment the negative wealth transfer effect. Alternatively, the new lower exercise price might restore or enhance managerial incentives to seek out profitable projects. This "good news" will at least partly offset the wealth-transfer and signaling effects. The net effect is an empirical question.

We also examine other potential determinants of cross-sectional variation in stock price reaction: residual standard deviation, market-to-book ratio, firm size, a measure of the magnitude of the cash flow from warrant exercise, and the percent reduction in exercise price.

\section{Data and method of analysis}

For our sample period, January 1980 through January 1997, we searched the Dow Jones News Retrieval service for announcements of reductions in exercise prices using the key words "warrant," "common stock purchase warrant," and "exercise price". The initial sample comprised 440 announcements. We eliminated 71 announcements that represented antidilutive adjustments, and another 35 that were missing information about either the new or old exercise price.

Of the remaining 334 announcements, 267 have associated returns available on the CRSP tape. These announcements, from 206 different firms, represent the stock sample. We printed out the headline, time stamp, and text of the announcement, and confirmed that the announcement did not contain news unrelated to the warrant. Table 1 reports the distribution of the 267 announcements by year and month for the two samples. We see no discernible concentration of announcements in any year or month, although announcements are somewhat more frequent in the 1990s.

For each of the 267 announcements, we searched the S\&P Daily Stock Price Record for data on the warrants. We found data for 140 warrants whose exercise price was reduced, and these 140 warrants constitute the warrant sample.

We also construct a control stock sample matched on industry (two-digit SIC code) and size (market value of equity). We use accounting data from 
Table 1

Chronological distribution of announcements of warrant exercise price reductions

Distribution by year (Panel A) and month (Panel B) of 267 announcements of warrant price reductions, January 1980 through January 1997. There are 154 conversion-forcing reductions and 113 long-term reductions.

\begin{tabular}{|c|c|c|c|c|}
\hline Year & $\begin{array}{l}\text { Conversion-forcing } \\
\text { (CF) reductions }\end{array}$ & $\begin{array}{l}\text { Percent of all } \\
\text { CF reductions }\end{array}$ & $\begin{array}{l}\text { Long-term } \\
\text { (LT) reductions }\end{array}$ & $\begin{array}{l}\text { Percent of all } \\
\text { LT reductions }\end{array}$ \\
\hline
\end{tabular}

Panel A. By year

$\begin{array}{rrrrr}1980 & 1 & 0.65 & 1 & 0.88 \\ 1981 & 0 & 0.00 & 1 & 0.88 \\ 1982 & 7 & 4.55 & 4 & 3.54 \\ 1983 & 10 & 6.49 & 4 & 3.54 \\ 1984 & 2 & 1.30 & 3 & 2.65 \\ 1985 & 8 & 5.19 & 7 & 6.19 \\ 1986 & 6 & 3.90 & 4 & 3.54 \\ 1987 & 13 & 8.44 & 7 & 6.19 \\ 1988 & 5 & 3.25 & 5 & 4.42 \\ 1989 & 9 & 5.84 & 10 & 8.85 \\ 1990 & 17 & 11.04 & 7 & 6.19 \\ 1991 & 14 & 9.09 & 4 & 3.54 \\ 1992 & 10 & 6.49 & 4 & 3.54 \\ 1993 & 15 & 9.74 & 6 & 5.31 \\ 1994 & 16 & 10.39 & 11 & 9.73 \\ 1995 & 12 & 7.79 & 22 & 19.47 \\ 1996 & 9 & 5.84 & 11 & 9.73 \\ 1997 & 0 & 0.00 & 2 & 1.77\end{array}$

Panel B. By month

\begin{tabular}{lrrrl} 
January & 13 & 8.44 & 10 & 8.85 \\
February & 15 & 9.74 & 9 & 7.96 \\
March & 15 & 9.74 & 11 & 9.73 \\
April & 14 & 9.09 & 10 & 8.85 \\
May & 10.49 & 8 & 7.08 \\
June & 16 & 10.39 & 8 & 7.08 \\
July & 18 & 11.69 & 9 & 7.96 \\
August & 12 & 7.79 & 11 & 9.73 \\
September & 12 & 7.79 & 9 & 7.96 \\
October & 16 & 10.39 & 10 & 8.85 \\
November & 9 & 5.84 & 7 & 6.19 \\
December & 4 & 2.60 & 11 & 9.73 \\
\hline
\end{tabular}

Compustat to construct descriptive statistics for the sample firms and their controls.

We conduct event studies to examine the warrant and stock price reactions to the reduction announcements. For the warrants, we report average (raw) returns for an interval centered on the announcement day, and test for 
significance using a cross-sectional $t$-test. We use unadjusted returns rather than abnormal returns because we are interested in the revaluation of the warrants in response to the announcement.

For the stocks, we use standard event-study procedures to calculate abnormal returns. Our estimation period starts 120 days before the announcement and ends ten days before the announcement. The CRSP Nasdaq index is our market proxy. We also use the S\&P 500 index, and the CRSP value-weighted and equally weighted indexes, with similar results. We assess the significance of the abnormal returns using the Boehmer et al. (1991) standardized cross-sectional $t$-statistic.

The change in the value of the warrants underestimates the size of the wealth transfer to warrantholders. Let $W$ represent the warrant price, $S$ the stock price, and $X$ the exercise price. Consider the effect on warrant value of the change in exercise price and the change in stock price. We assume the BlackScholes model:

$$
W=N\left(d_{1}\right) S-\mathrm{e}^{-r t} N\left(d_{2}\right) X
$$

and

$$
\begin{aligned}
& \mathrm{d} W=(\partial W / \partial S) \mathrm{d} S+(\partial W / \partial X) \mathrm{d} X \\
& =N\left(d_{1}\right) \mathrm{d} S-\mathrm{e}^{-r t} N\left(d_{2}\right) \mathrm{d} X .
\end{aligned}
$$

The stock price will change because of the wealth transfer $\left(\mathrm{d} S_{\mathrm{W}}\right)$ and because of information associated with the announcement $\left(\mathrm{d} S_{\mathrm{I}}\right)$. That is, $\mathrm{d} S=\mathrm{d} S_{\mathrm{W}}+\mathrm{d} S_{\mathrm{I}}$, so we can write

$$
\mathrm{d} W=N\left(d_{1}\right)\left[\mathrm{d} S_{\mathrm{W}}+\mathrm{d} S_{\mathrm{I}}\right]-\mathrm{e}^{-r t} N\left(d_{2}\right) \mathrm{d} X .
$$

Rearranging,

$$
\mathrm{d} W=N\left(d_{1}\right) \mathrm{d} S_{\mathrm{W}}-\mathrm{e}^{-r t} N\left(d_{2}\right) \mathrm{d} X+N\left(d_{1}\right) \mathrm{d} S_{\mathrm{I}} .
$$

The change in warrant value thus has three components. The first two components constitute the wealth transfer effect, and the third reflects the loss in warrant value because of the negative information effect on the stock price $\left(\mathrm{d} S_{\mathrm{I}}<0\right)$. Thus, the change in warrant value understates the wealth transfer. Similarly, using the change in stock price as a measure of the wealth transfer losses to shareholders results in an overstatement of those losses. Nonetheless, because $\mathrm{d} S$ (and hence $\mathrm{d} S_{\mathrm{I}}$ ) is empirically small, we use the total change in warrant value as our measure of the wealth transfer.

We investigate the wealth transfer effect in two ways. First, we compare the total dollar amount by which the warrants increase in value to the total dollar losses of shareholders. For the conversion-forcing sample, the difference is the net magnitude of the cost savings and the SEO effect. For the long-term sample, the difference is the net magnitude of the negative information and the incentive realignment effect. 
Second, we regress the dollar losses to shareholders on the dollar gains to warrantholders:

\$losses to shareholders $=a+b^{*}$ \$gains to warrantholders $+e$.

In a perfect market, there would be a dollar-for-dollar tradeoff between warrantholder gains and shareholder losses. In this case, the intercept would be zero and the slope would be equal to one. For the conversion-forcing sample, a significant nonzero intercept would indicate the sign of the net effect of the cost savings and the SEO effect. For the long-term sample, a significant nonzero intercept would indicate the sign of the net effect of the negative information and incentive realignment effect.

We investigate cross-sectional variation in the stock price response in two ways. First, we partition the conversion-forcing sample according to whether the announcement contains information about the use of the exercise proceeds. Second, we calculate the correlations of the stock price reaction (the day 0 abnormal return) with explanatory variables, and then estimate multiple regression models with the stock price reaction as the dependent variable. The explanatory variables differ across the two samples.

\subsection{Explanatory variables, conversion-forcing sample}

In a perfect market, there would be no adverse-selection problem because all participants would be equally well informed. However, in the presence of information asymmetry, capital providers are concerned about adverse selection and there will be contracting costs associated with adverse selection. Following Krishnaswami et al. (1999) and others, we use the standard deviation of the market model residuals (RSD) from the estimation period as a proxy for information asymmetry. We assume that investors and managers are equally well informed about marketwide factors, but that managers have the advantage of firm-specific information. Krishnaswami et al. find that firms with greater information asymmetry rely more on private debt than do other firms, because the contracting costs associated with adverse selection are lower when dealing with (better informed) private lenders. This finding supports RSD as a reasonable proxy for information asymmetry.

If adverse-selection problems are more acute in firms with higher information asymmetries, the coefficient on RSD should be negative for the sample of conversion-forcing firms. That is, the greater the information disparity between managers and investors, the greater the potential for adverse selection, and the more negative will be the stock price reaction.

As in Smith and Watts (1992) and Barclay and Smith (1995a,b), we use the market-to-book ratio $(\mathrm{M} / \mathrm{B})$ as a measure of growth opportunities. If we assume that the proceeds from the warrant exercise are invested profitably rather than squandered, then a firm with better growth opportunities should 
experience a less negative reaction to the announcement. We would then expect a positive coefficient on M/B. However, Krishnaswami et al. (1999) interpret the market-to-book ratio as a measure of the contracting costs associated with the potential for moral hazard (underinvestment or asset substitution). Were this the case, the greater the potential for moral hazard, the more negative would be the stock price reaction, and we would expect a negative coefficient on $\mathrm{M} / \mathrm{B}$.

The market value of equity (EQUITY) is a measure of firm size. Smaller firms face higher transaction costs when directly accessing the capital market (Smith, 1977; Altinkiliç and Hansen, 2000). Raising capital from warrant exercise saves on transaction costs. Therefore, we expect a negative sign for the coefficient on EQUITY.

We measure the magnitude of the financing, \%INFLOW, by the dollar inflow from warrant exercise divided by the firm's market value of equity. In the Miller and Rock (1985) cash flow signaling argument, larger issue sizes are associated with more negative stock price reactions. Some empirical evidence supports this view (e.g., Asquith and Mullins, 1986). Therefore, we expect that the coefficient on \% INFLOW will be negative.

Finally, we assess whether the percent reduction in exercise price influences the stock price reaction. If a greater reduction in exercise price constitutes a greater "giveaway" to warrantholders, we expect to observe a negative coefficient on REDUCE, the variable that represents the percent of reduction in the exercise price.

\subsection{Explanatory variables, long-term sample}

Information asymmetry can influence the stock price reaction to long-term reductions. The decision to reduce a warrant's exercise price long-term (that is, for more than 60 days and in the absence of dividends) is an admission by managers that there is only a slight probability of the stock price rising above the old exercise price. This information represents particularly bad news for the future value of the shares. Further, the greater the degree of information asymmetry, the bigger the "surprise" associated with the announcement, and the more negative will be the stock price reaction. Therefore, we expect a negative coefficient on RSD, the residual standard deviation.

Exercise price reduction increases the probability that the warrants will be exercised. The increase in probability is good news for firms with good investment opportunities, and leads to a positive sign for the coefficient on $\mathrm{M} / \mathrm{B}$. But if $\mathrm{M} / \mathrm{B}$ is a measure of contracting costs associated with moral hazard, as argued by Krishnaswami et al. (1999), then we would expect a negative coefficient on $\mathrm{M} / \mathrm{B}$.

As noted earlier, firm size measures potential transaction costs saved (albeit not immediately for the long-term sample). Thus, the predicted sign on EQUITY is negative. Again, the percent reduction in the warrant exercise price 
(REDUCE) measures the amount of "giveaway" to warrantholders, and we expect its coefficient to be negative. Finally, the variable \%INFLOW is not relevant to the long-term sample because those announcements do not result in an immediate inflow of capital.

Table 2 summarizes the predictions for the two samples.

\subsection{Long-run performance}

We track and compare the failure rates and long-run performance of the conversion-forcing firms and their control firms. If the firms use their option to reduce exercise price wisely, the firms should not fail at a higher rate. However, an agency-cost explanation for warrants suggests that many warrant-issuing firms will discover that they have no positive NPV projects. In these cases, the firms should fail at a greater than normal rate and should underperform their controls.

We also track the failure rates and long-run performance of the long-term sample firms. Underperformance by these firms would indicate that resetting the exercise price is not a mechanism for restoring managerial incentives.

Table 2

Predicted signs of correlations and coefficients in regressions for conversion-forcing and long-term reductions in warrant exercise price

The dependent variable is the day 0 abnormal stock return. The independent variables are RSD, the standard deviation of market model residuals from the estimation period; $\mathrm{M} / \mathrm{B}$, the marketto-book ratio; EQUITY, the market value of equity; \%INFLOW, the dollar inflow from warrant exercise expressed as a percent of market value of equity; and REDUCE, the percent reduction in exercise price.

\begin{tabular}{|c|c|c|c|c|}
\hline \multirow[t]{2}{*}{ Variable } & \multicolumn{2}{|c|}{ Conversion-forcing sample } & \multicolumn{2}{|c|}{ Long-term sample } \\
\hline & Predicted sign & Rationale & Predicted sign & Rationale \\
\hline RSD & Negative & $\begin{array}{l}\text { Information } \\
\text { asymmetry leads } \\
\text { to contracting costs } \\
\text { due to adverse } \\
\text { selection }\end{array}$ & Negative & $\begin{array}{l}\text { Information } \\
\text { asymmetry leads } \\
\text { to greater (negative) } \\
\text { surprise }\end{array}$ \\
\hline $\mathrm{M} / \mathrm{B}$ & $\begin{array}{l}\text { Positive or } \\
\text { negative }\end{array}$ & $\begin{array}{l}\text { Growth options }(+), \\
\text { contracting costs due } \\
\text { to moral hazard }(-)\end{array}$ & $\begin{array}{l}\text { Positive or } \\
\text { negative }\end{array}$ & $\begin{array}{l}\text { Growth options } \\
(+) \text {, contracting } \\
\text { costs due to moral } \\
\text { hazard }(-)\end{array}$ \\
\hline EQUITY & Negative & Cost saving & Negative & Cost saving \\
\hline$\%$ INFLOW & Negative & Miller-Rock signal & Not applicable & $\begin{array}{l}\text { No immediate } \\
\text { inflow of capital }\end{array}$ \\
\hline REDUCE & Negative & Giveaway effect & Negative & Giveaway effect \\
\hline
\end{tabular}




\section{Initial findings}

We could categorize a reduction as conversion-forcing if the intrinsic value at the lower exercise price exceeds the warrant's ongoing value at the higher exercise price, and we could estimate the warrant's ongoing value using a warrant pricing model. However, this approach introduces the possibility of model misspecification. Rather than choosing among warrant pricing models, we provide some indirect evidence on our sample division procedure. We have quarterly data on the number of warrants outstanding for 48 of the warrants in the conversion-forcing sample. In the quarter following the announcement, the number of warrants outstanding drops by $92.33 \%$, suggesting that most of the warrants are exercised. This observation supports the data in Table 4, which shows that the conversion-forcing reductions involve warrants that are usually a little out of the money before the reduction and well in the money after. Therefore, we believe that the classification scheme we have adopted is reasonable.

\subsection{Descriptive data}

We define a reduction in warrant exercise price as "conversion forcing" if either the reduction is temporary (30 days is typical), or the reduction is permanent but the remaining warrant life is 60 days or less. We categorize observations that do not meet either of the two criteria as "long-term" reductions. The overall sample contains 154 (58\%) conversion-forcing reductions and $113(42 \%)$ long-term reductions.

Panel A of Table 3 reports the characteristics of the sample firms, and Panel $\mathrm{B}$ reports the characteristics of the control firms. Data are not available for all firms for all variables, so we report the sample size for each cell in the table. Because the data are skewed, we report the medians as well as the means of the variables.

The first row of Panel A shows the market value of equity, which we calculate as the number of shares outstanding times the price per share two days before the announcement. The sample firms are small firms. The conversion-forcing firms have a median market value of equity of $\$ 13.29$ million, and an average market equity value of $\$ 45.52$ million. For the longterm reductions, the median market value is $\$ 8.84$ million, with an average of $\$ 16.07$ million. The median size for the long-term reductions is significantly less (at the $5 \%$ level) than the median for the conversion-forcing reductions, but the means are not significantly different.

The first row of Panel B, Table 3, shows the market value of equity for the control firms. The control firms do not differ materially from the sample firms in terms of market value of equity. This finding confirms the efficacy of the matching procedure. 
Table 3

Descriptive statistics

Panel A: Sample firms

Means, medians, and sample sizes for characteristics of firms that announce a reduction in the exercise price of warrants. Market value of equity is the price per share two days prior to the announcement multiplied by the number of shares outstanding. Market-to-book ratio is the market value of equity plus the book value of debt divided by the book value of total assets. Age is the number of years from listing until the announcement. Long-term debt and total assets are book values, measured at the end of the year prior to the announcement. Operating earnings per share is net income before extraordinary items divided by shares outstanding. R\&D is research and development expenditures. $R \& D$ and sales are measured at the end of the year prior to the announcement.

\begin{tabular}{lcc}
\hline Variable & Conversion-forcing reductions & Long-term reductions \\
\cline { 2 - 3 } & mean & mean \\
& $($ median $)$ & (median) \\
& {$[$ sample size] } & [sample size] \\
\hline Market value of equity (\$ million) & 45.52 & 16.07 \\
& $(13.29)$ & $(8.84)^{\mathrm{a}}$ \\
Market-to-book ratio & {$[151]$} & {$[111]$} \\
& 5.95 & 3.69 \\
Age (years) & $(1.98)$ & $(2.08)$ \\
& {$[130]$} & {$[95]$} \\
Long-term debt/Total assets & 5.83 & 5.82 \\
& $(3.66)$ & $(4.06)$ \\
Operating earnings per share $(\$)$ & {$[154]$} & {$[113]$} \\
& 0.18 & $0.13 \mathrm{~b}$ \\
year 0 to year +1 (\%) & $(0.09)$ & $(0.04)$ \\
& {$[130]$} & {$[95]$} \\
R\&D/Sales & -0.39 & -0.42 \\
& $(-0.12)$ & $(-0.19)$ \\
& {$[131]$} & {$[89]$} \\
& 0.14 & 0.14 \\
& $(0.04)$ & $(0.06)$ \\
& {$[44]$} & {$[44]$} \\
& 43.95 & 57.12 \\
& $(0.00)$ & $(16.67)$ \\
& {$[107]$} & {$[71]$}
\end{tabular}

Panel B: Control firms

Means, medians, and sample sizes for control firms matched by two-digit SIC code and size.

$\begin{array}{lcr}\text { Market value of equity (\$ million) } & 48.94 & 23.40 \\ & (13.41) & (9.31) \\ \text { Market-to-book ratio } & {[151]} & {[111]} \\ & 2.01^{\mathrm{c}} & 2.18^{\mathrm{c}} \\ & (1.14)^{\mathrm{d}} & (1.07)^{\mathrm{d}} \\ \text { Age (years) } & {[135]} & {[94]} \\ & 11.03^{\mathrm{c}} & 11.32^{\mathrm{c}} \\ & (8.11)^{\mathrm{d}} & (9.22)^{\mathrm{d}} \\ & {[151]} & {[111]}\end{array}$


Table 3 (continued)

\begin{tabular}{lcc}
\hline Variable & Conversion-forcing reductions & Long-term reductions \\
\cline { 2 - 3 } & $\begin{array}{c}\text { mean } \\
\text { (median) } \\
\text { [sample size] }\end{array}$ & $\begin{array}{c}\text { mean } \\
\text { (median) } \\
\text { [sample size] }\end{array}$ \\
\hline Long-term debt/Total assets & 0.18 & 0.17 \\
& $(0.12)$ & $(0.07)$ \\
Operating earnings per share $(\$)$ & {$[135]$} & {$[93]$} \\
& 0.76 & -0.14 \\
R\&D/Sales & $(0.09)^{\mathrm{d}}$ & $(0.02)^{\mathrm{d}}$ \\
& {$[132]$} & {$[93]$} \\
Increase in capital expenditures, & 0.07 & $(0.08$ \\
year 0 to year +1 (\%) & $(0.02)$ & {$[43]$} \\
& {$[52]$} & 29.72 \\
& 22.78 & $(-0.12)$ \\
\hline
\end{tabular}

\footnotetext{
${ }^{a}$ Median is significantly different from the median of the sample of conversion-forcing reductions at the $5 \%$ level.

${ }^{\mathrm{b}}$ Mean is significantly different from the mean of the sample of conversion-forcing reductions at the $5 \%$ level.

${ }^{\mathrm{c}}$ Mean is significantly different from the mean of the sample firms at the $5 \%$ level.

${ }^{\mathrm{d}}$ Median is significantly different from the median of the sample firms at the $5 \%$ level.
}

The second row of each panel of Table 3 reports the market-to-book ratio, which we use as our measure of growth opportunities. In Panel A, the median market-to-book ratios are 1.98 (conversion-forcing sample) and 2.08 (longterm sample). The medians are not statistically different, nor are the means (5.95 and 3.69). However, as we can see in Panel B, both samples show higher market-to-book ratios than do their controls. In each case, both the median and mean are higher for the sample firms, which suggests that the sample firms are growth firms that derive much of their value from growth opportunities rather than assets-in-place.

We also report the age of the firms in Table 3, measured as the number of years from listing to the announcement date. The sample firms are young relative to their controls. The conversion-forcing firms show a median age of 3.66 years, compared to 8.11 years for the control firms. The long-term firms have a median age of 4.06 years, compared to 9.22 years for their controls. Both the means and medians are significantly lower for the sample firms relative to the control firms.

Table 3 also shows the ratio of long-term debt to total assets, both measured as book values. The medians are 0.09 for the conversion-forcing sample and 0.04 for the long-term sample. These medians are not significantly different from each other. The mean debt ratio for the long-term sample $(0.13)$ is 
significantly less than that of the conversion-forcing sample (0.18). The debt ratios of the two samples do not differ reliably from those of their control firms.

Operating earnings per share is our measure of performance. We compute EPS as net income before extraordinary items divided by number of shares outstanding. We take these variables from Compustat for the year before the announcement. We report operating EPS calculated using shares outstanding. Our inferences do not change if we use fully diluted EPS. Because the accounting system does not capture the intangible assets characteristic of growth firms, EPS may be a poor measure of performance for our sample firms.

The sample firms have negative earnings. The conversion-forcing sample has a median EPS of $-\$ 0.12$ and the long-term sample has a median of $-\$ 0.19$. These medians are not significantly different from each other. However, the sample firms do have significantly lower EPS than their controls, as measured by the median EPS. The poor performance by the sample firms is consistent with their warrants being out of the money at the time of the announcement.

We assume that higher levels of research and development indicate growth opportunities. Therefore, we calculate the ratio of R\&D expenditures to sales as an alternative measure of growth. The row labeled "R\&D/Sales" in Table 3 reports this ratio. In Panel $\mathrm{A}$, we see that the conversion-forcing firms have median R\&D expenditures of $4 \%$ of sales, and the long-term firms have a median of $6 \%$. Panel $\mathrm{B}$ of Table 3 shows that the R\&D ratios for the sample firms do not differ from those of their control firms.

The last row of the table reports the percent increase in capital expenditures in the year following the announcement, using the year of the announcement as the base. The means and medians of the two samples do not differ significantly (Panel A), nor do the sample firms' numbers differ from those of their controls (Panel B).

From Table 3, we see that our sample firms (both conversion-forcing and long-term) tend to be small and young, with high market-to-book ratios and poor accounting performance. These characteristics are consistent with Schultz's (1993a) agency-cost theory about firms that issue warrants. Firms that announce conversion-forcing reductions do not appear to be fundamentally different from firms that announce long-term reductions. This conclusion is further supported by a logistic regression (not reported) using the variables in Table 3 .

Table 4 provides information about the reductions in exercise price. On average, the warrants in the conversion-forcing sample are $18 \%(\$ 1.04)$ out of the money just before the announcement, with a median of $22 \%(\$ 0.96)$. The warrants in the long-term sample average 38\% (\$2.81) out of the money, with a median of $48 \%(\$ 2.50)$. Both in percent and in dollar terms, the differences between the conversion-forcing and long-term samples are statistically significant at the 5\% level.

After the reduction in exercise price, the conversion-forcing sample averages $36 \%(\$ 1.04)$ in the money, with a median of 33\% (\$0.94). The warrants in the long-term reduction sample are nearly at the money after the reduction in 
Table 4

Descriptive statistics for reductions in warrant exercise price

$\left(S-X_{\text {old }}\right) / X_{\text {old }}$ measures the moneyness of the warrants prior to the reduction in exercise price. $S$ is the stock price two days prior to the announcement and $X_{\text {old }}$ is the old exercise price. $\left(S-X_{\text {new }}\right) / X_{\text {new }}$ measures the moneyness of the warrants after the reduction in exercise price. $X_{\text {new }}$ is the new exercise price. $\left(X_{\text {old }}-X_{\text {new }}\right) / X_{\text {old }}$ measures the percent reduction in exercise price.

\begin{tabular}{cccc}
\hline Mean & Median & Minimum & Maximum \\
\hline
\end{tabular}

Panel A: Conversion-forcing reductions

$\begin{array}{lrrrr}\left(S-X_{\text {old }}\right) / X_{\text {old }} & -0.18 & -0.22 & -0.94 & 4.85 \\ \left(S-X_{\text {new }}\right) / X_{\text {new }} & 0.36 & 0.33 & -0.86 & 8.75 \\ \left(X_{\text {old }}-X_{\text {new }}\right) / X_{\text {old }} & 0.39 & 0.37 & 0.01 & 0.93 \\ \left(S-X_{\text {old }}\right)(\$) & -1.04 & -0.96 & -28.13 & 25.70 \\ \left(S-X_{\text {new }}\right)(\$) & 1.04 & 0.94 & -6.76 & 27.82 \\ \left(X_{\text {old }}-X_{\text {new }}\right)(\$) & 2.08 & 1.75 & 0.10 & 25.00\end{array}$

Panel B: Long-term reductions

$\begin{array}{lccrr}\left(S-X_{\text {old }}\right) / X_{\text {old }} & -0.38^{\mathrm{a}} & -0.48^{\mathrm{b}} & -0.98 & 1.25 \\ \left(S-X_{\text {new }}\right) / X_{\text {new }} & 0.00^{\mathrm{a}} & 0.01^{\mathrm{b}} & -0.93 & 3.08 \\ \left(X_{\text {old }}-X_{\text {new }}\right) / X_{\text {old }} & 0.37 & 0.33 & 0.02 & 0.93 \\ \left(S-X_{\text {old }}\right)(\$) & -2.81^{\mathrm{a}} & -2.50^{\mathrm{b}} & -37.13 & 2.50 \\ \left(S-X_{\text {new }}\right)(\$) & 0.25^{\mathrm{a}} & 0.13 & -12.00 & 4.13 \\ \left(X_{\text {old }}-X_{\text {new }}\right)(\$) & 3.06 & 1.40 & 0.04 & 31.50\end{array}$

${ }^{\text {a }}$ Significantly different from the mean of the conversion-forcing sample at the $5 \%$ level.

${ }^{\mathrm{b}}$ Significantly different from the median of the conversion-forcing sample at the $5 \%$ level.

exercise price. They average $0.4 \%(\$ 0.25)$ in the money, with a median of $0.9 \%$ (\$0.13). Here again, the post-announcement moneyness of the long-term sample is significantly different from that of the conversion-forcing sample. Our finding that the long-term reductions involve resetting the exercise price (close) to the current stock price is consistent with a "managerial incentive" rationale for the resetting of the warrant exercise price (Hall and Murphy, 2000).

Our sample of conversion-forcing exercise price reductions involves warrants that are modestly out of the money and become well in the money. The sample of long-term exercise price reductions involves warrants that are well out of the money and become near the money.

\subsection{Event studies}

Table 5 presents the warrant returns around the announcement date (event day 0 ). For conversion-forcing reductions, the warrant increases by $6.54 \%$ on the announcement day, which is significantly greater than zero. Although no other day's average return is individually distinguishable from zero in the $[-5$, +5 ] interval, the cumulative return over the 11-day window exceeds $17 \%$. For long-term reductions, the average announcement-day return is $9.82 \%$, also 
Table 5

Returns of warrants around the announcement of a reduction in exercise price

For each event day, the table reports the average percent return of the warrants of firms that announced a reduction of warrant exercise price on day 0 . We calculate returns from closing prices or bid-ask midpoints and $t$-statistics by using the cross-sectional standard error for each day.

\begin{tabular}{lcc}
\hline Event day & $\begin{array}{c}\text { Conversion-forcing } \\
\text { reductions }(n=64)\end{array}$ & $\begin{array}{c}\text { Long-term reductions } \\
(n=76)\end{array}$ \\
\hline-5 & 1.53 & 1.35 \\
-4 & 0.88 & 0.71 \\
-3 & -0.08 & -0.04 \\
-2 & 1.92 & 1.86 \\
-1 & -0.73 & 1.44 \\
0 & $6.54^{\mathrm{a}}$ & $9.82^{\mathrm{a}}$ \\
+1 & 2.68 & 0.38 \\
+2 & 0.35 & 0.41 \\
+3 & 0.64 & 1.73 \\
+4 & 1.61 & 0.73 \\
+5 & 1.84 & 1.18 \\
\hline
\end{tabular}

${ }^{\mathrm{a}}$ Significant at the $1 \%$ level.

significantly greater than zero. The cumulative 11-day return for this sample exceeds $19 \%$. The evidence in Table 5 shows that, in response to the announcement of a reduction in exercise price, warrants increase in value.

Table 6 shows the stock price reactions of the two samples to the announcement of a reduction in exercise price. The conversion-forcing sample has an average abnormal return of $-1.53 \%$ on day 0 , which is significant at the $5 \%$ level. No other day in the 11-day interval has a statistically significant abnormal return. On day $0,59.1 \%$ of the firms have a negative abnormal return. The cumulative abnormal return over the $[-5,+5]$ interval is $-2.05 \%$.

The long-term sample has an average day 0 abnormal return of $-1.15 \%$, which is significant at the $1 \%$ level. On day $0,55.4 \%$ of the firms have a negative abnormal return. Over the $[-5,+5]$ interval, the cumulative abnormal return for this sample is $-1.56 \%$.

Because the conversion-forcing reductions are equity-raising events, one benchmark by which to judge the stock price reaction to conversion-forcing reductions is to compare it to the price reaction to seasoned equity offerings (SEOs). Mikkelson and Partch (1986) report an average two-day abnormal return of $-3.56 \%$ for 80 SEOs, and $-4.46 \%$ for seasoned common stock offerings with no contemporaneous events. Based on five separate studies, Smith (1986) reports an average two-day announcement-period return of $-3.14 \%$.

The firms in our samples have outcomes that are no worse than those documented in the literature. Admittedly, a comparison of our findings with 
Table 6

Abnormal returns of common stock around the announcement of a reduction in warrant exercise price

For each event day, the table reports the average abnormal return (in percent) of the common stocks of firms that announced a reduction of warrant exercise price on day 0 . Tests of significance use the Boehmer, Musumeci, and Poulsen (1991) $t$-statistic. We estimate abnormal returns using the market model with parameters estimated from day -120 to day -10 . The CRSP Nasdaq index is the market proxy.

\begin{tabular}{lcccc}
\hline Event day & $\begin{array}{c}\text { Conversion-forcing } \\
\text { reductions }(n=154)\end{array}$ & $\%<0$ & $\begin{array}{c}\text { Long-term } \\
\text { reductions }(n=113)\end{array}$ & $\%<0$ \\
\hline-5 & -0.43 & 53.2 & 1.10 & 48.7 \\
-4 & 0.15 & 46.1 & 0.07 & 58.4 \\
-3 & 0.01 & 55.2 & -0.30 & 50.4 \\
-2 & 0.85 & 52.6 & -0.87 & 61.1 \\
-1 & 0.16 & 51.3 & -0.11 & 55.4 \\
0 & $-1.53^{\mathrm{a}}$ & 59.1 & $-1.15^{\mathrm{b}}$ & 55.4 \\
+1 & -0.11 & 59.7 & -0.14 & 54.9 \\
+2 & -0.95 & 59.5 & 0.30 & 54.0 \\
+3 & 0.58 & 54.9 & 0.05 & 53.1 \\
+4 & -0.71 & 56.2 & -0.09 & 56.6 \\
+5 & -0.07 & 61.4 & -0.42 & 55.8 \\
\hline
\end{tabular}

${ }^{\text {a }}$ Significant at the $5 \%$ level.

${ }^{\mathrm{b}}$ Significant at the $1 \%$ level.

the literature on SEOs might not be appropriate, because the firms that constitute the various samples might not be similar. However, the characteristics of the firms in our samples (e.g., small, young, growth firms) suggest that they should experience a larger stock price decline in response to an equity financing announcement. We conclude that the price declines of our sample firms are small relative to what we would expect if they undertook an SEO.

\subsection{Wealth transfer}

Another way we can benchmark the observed stock price reactions to exercise price reductions is to account explicitly for the magnitude of the wealth transfer. We are able to find the number of warrants outstanding for 99 of the sample firms, 48 of which are in the conversion-forcing sample and 51 are in the longterm sample. For both samples, we compute the aggregate dollar gain to warrantholders and the aggregate dollar loss to shareholders. As discussed in Section 3, this approach underestimates the magnitude of the wealth transfer.

On day 0, warrantholders in the conversion-forcing sample gain $\$ 2.73$ million and shareholders lose $\$ 18.49$ million. For the long-term sample, warrantholders gain $\$ 4.32$ million and shareholders lose \$21.65 million. Thus the announcement is not merely a wealth transfer, but also carries negative 
information content. An intra-industry analysis (not reported) shows no stock price reaction for the firms' competitors. We conclude that the information is conveyed by the reduction announcement is firm-specific.

For the conversion-forcing sample, we estimate Eq. (6) in millions of dollars (with $t$-statistics in parentheses). We find:

\$losses to shareholders $=-0.442+0.985 *$ \$gains to warrantholders.

$$
(-3.55) \quad(3.74)
$$

The intercept is significant and negative, which indicates that an SEO effect dominates the cost savings. This finding provides additional support for a significant SEO effect in addition to the wealth transfer effect. The intercept implies that even if shareholders did not suffer from a wealth transfer effect, they would lose $\$ 442,000$ at the announcement of a reduction in the warrant exercise price. For the conversion-forcing firms, this represents about $3.33 \%$ of the median market value of equity. The slope coefficient is significantly greater than zero, and insignificantly different from one.

We also estimate Eq. (6) in millions of dollars for the long-term sample:

\$losses to shareholders $=-0.514+1.053 *$ \$gains to warrantholders.

$$
(-2.60) \quad(2.68)
$$

The intercept is significant and negative, which indicates that negative information dominates the incentive realignment effect. The intercept implies that even if shareholders did not suffer from a wealth transfer effect, they would lose $\$ 514,000$ at the announcement of a reduction in warrant exercise price. For the long-term reduction sample, this represents about $5.81 \%$ of the median market value of equity. The slope coefficient is significantly greater than zero, and insignificantly different from one.

In our final examination of wealth transfer and other effects, we translate the dollar gains of warrantholders into the percent decline in the stock price that is associated with that dollar amount and adjust the abnormal stock returns by this percent decline. That is, we subtract from the abnormal stock return that part of the return attributable to the wealth-transfer effect. For the conversionforcing sample, the dollar gain to warrantholders translates into an average $0.30 \%$ stock price decline. Accounting for the wealth-transfer effect thus increases the day 0 abnormal return from $-1.53 \%$ to $-1.23 \%$. This figure represents the combined influences of the cost savings and the SEO effect.

For the long-term sample, the dollar gain to warrantholders translates into an average $0.36 \%$ stock price decline. Adjusting for the wealth-transfer effect increases the day 0 abnormal return for the sample from $-1.15 \%$ to $-0.79 \%$, which represents the combined influences of the negative-information and incentive-realignment effects.

We interpret the evidence in Table 6 and our analysis of the wealthtransfer effect as an indication that the wealth losses to shareholders at the 
announcement of a conversion-forcing reduction are not appreciably larger than we would expect to observe if the firms raised equity capital through alternative means, such as an underwritten offer. We conclude that the option to reduce the exercise price of a warrant is an efficient provision of the warrant agreement, and one which allows the firms to raise equity capital at reasonable cost.

\subsection{Use of the proceeds}

Some announcements from the conversion-forcing sample provide information on how management plans to use the proceeds from the warrant exercise. Three examples follow:

Proposed use of the net proceeds are [sic] principally the reduction of outstanding debtedness [sic] to affiliates and commercial lenders, the reduction of trade payables, and the purchase of additional inventory.

The company intends to use the proceeds from the exercise of the warrants primarily for acquisitional and working capital purposes.

The company said it reduced the exercise price of its class A warrants to generate new equity capital to be used by the company towards satisfying a portion of its current bank debt obligations and to provide additional working capital to the extent proceeds are not paid to the bank.

We divide the conversion-forcing sample by whether the announcement contains any information about the use of the proceeds. For the 31 companies that provide such information, the day 0 abnormal return is positive $1.03 \%$, which is significant at the $10 \%$ level. For companies in the conversion-forcing sample that provide no such information, the day 0 abnormal return is $-2.15 \%$. Using both parametric and nonparametric tests, we find that the difference between the two samples is significant at the $5 \%$ level.

\section{Correlation and regression results}

\subsection{Conversion-forcing sample}

Table 7 reports the correlation and regression results. Panel A reports the correlations of the announcement-day abnormal stock return with the variables described in Section 3. Panel B reports the regression results for the conversion-forcing sample.

Contrary to our expectations, the residual standard deviation (RSD) shows a significant and positive correlation with the stock price reaction for the conversion-forcing sample. This finding indicates that a firm with a higher residual standard deviation has a less negative stock price response. Panel B 
Table 7

Cross-sectional variation in stock price reaction

Panel A shows the correlation of the day 0 abnormal return with RSD, the standard deviation of market model residuals from the estimation period; $\mathrm{M} / \mathrm{B}$, the market-to-book ratio; EQUITY, the market value of equity; \%INFLOW, the dollar inflow from warrant exercise expressed as a percent of market value of equity; and REDUCE, the percent reduction in exercise price. Panels $\mathrm{B}$ and $\mathrm{C}$ show regression models in which the day 0 abnormal return is the dependent variable; independent variables are listed above. Sample sizes shown in brackets.

Panel A: Correlation of day 0 abnormal return with other variables

\begin{tabular}{lcc}
$\begin{array}{l}\text { Correlation of day 0 } \\
\text { abnormal return with: }\end{array}$ & $\begin{array}{c}\text { Conversion-forcing } \\
\text { reductions }\end{array}$ & $\begin{array}{c}\text { Long-term } \\
\text { reductions }\end{array}$ \\
\hline RSD & $0.105^{\mathrm{a}}$ & $0.068^{\mathrm{a}}$ \\
M/B & {$[154]$} & {$[112]$} \\
EQUITY & $0.039^{\mathrm{a}}$ & 0.058 \\
& {$[130]$} & {$[95]$} \\
\%INFLOW & 0.017 & 0.086 \\
& {$[151]$} & {$[110]$} \\
REDUCE & -0.037 & $\mathrm{n} / \mathrm{a}^{\mathrm{b}}$
\end{tabular}

Panel B: Regression results for conversion-forcing reductions

\begin{tabular}{lcc} 
Independent variables & Model (1) & Model (2) \\
\hline RSD & $0.473^{\mathrm{a}}$ & $0.221^{\mathrm{a}}$ \\
M/B & 0.012 & 0.027 \\
EQUITY & 0.000 & 0.000 \\
\%INFLOW & -0.013 & \\
REDUCE & $-0.043^{\mathrm{a}}$ & $-0.029^{\mathrm{a}}$ \\
Sample size & 41 & 130 \\
$R^{2}$ & 0.257 & 0.070
\end{tabular}

Panel C: Regression results for long-term reductions

Independent variables

Model (1)

\begin{tabular}{lc}
\hline RSD & $0.115^{\mathrm{a}}$ \\
M/B & 0.005 \\
EQUITY & 0.001 \\
REDUCE & $-0.032^{\mathrm{a}}$ \\
Sample size & 95 \\
$R^{2}$ & 0.093 \\
\hline
\end{tabular}

${ }^{a}$ Significant at the $5 \%$ level.

${ }^{\mathrm{b}}$ Not applicable. 
shows that the relation is preserved in a multivariate setting. We have no conclusive explanation for this result. It is possible that RSD is serving as a proxy for something other than information asymmetry.

For the conversion-forcing sample, the market-to-book ratio also shows a significant and positive correlation with the abnormal stock return on day 0 . We interpret this finding to mean that a firm with better growth opportunities experiences a less negative stock price reaction. This interpretation is consistent with the notion that the market expects the proceeds from warrant exercise to be invested in profitable growth opportunities.

The size of the firm, measured by the market value of equity, is not significantly correlated with the day 0 abnormal return. There might not be sufficient variation in the variable across the sample firms to detect a relation, or firm size might not influence the stock price reaction.

We calculate the variable \%INFLOW by the dollar inflow from warrant exercise (at the new exercise price) divided by the market value of equity two days prior to the announcement. We have 48 observations in the conversionforcing sample for \%INFLOW because, as noted earlier, the number of warrants outstanding is not available for many of the sample firms. $\%$ INFLOW is not significantly related to the announcement stock price reaction.

The correlation with REDUCE is significant and negative, showing that a greater reduction in the exercise price is associated with a more negative stock price reaction. The negative coefficient indicates a "giveaway" effect.

Table 7, Panel B, reports the regression results. In all cases, the dependent variable is the abnormal return on the common stock for the announcement day. (The results are similar if we use the cumulative abnormal return for days -1 and 0 or days -1 through +1 as the dependent variable.) For the conversionforcing sample, we estimate two models. Model (1) includes the five variables described in Section 3.1. However, primarily because the variable \% INFLOW has relatively few observations, the sample size for the model is small (41). Model (2) excludes \%INFLOW. The sample size is 130 for this model.

In Model (1), the coefficient on RSD is significant and positive, consistent with its positive correlation reported in Panel A. The market-to-book ratio is not significant at conventional levels, nor is EQUITY or \%INFLOW. The coefficient on REDUCE is significant and negative, consistent with its negative correlation in Panel A.

The results in Model (2) are similar. The coefficient on RSD is significant and positive, the coefficient on REDUCE is significant and negative, and no other coefficient is statistically distinguishable from zero.

For all regressions, including those reported next, we use the Belsley, Kuh, and Welsch condition index to assess the degree of multicollinearity. The maximum value for any regression is 5.7, well below the threshold value of 20 . 


\subsection{Long-term sample}

Table 7, Panel A, shows the correlations between the day 0 abnormal return and four variables. Again, contrary to our expectations, RSD is positively correlated with the stock price reaction. A firm with a high level of residual standard deviation has a less negative stock price reaction.

The market-to-book ratio is not significantly correlated with the day 0 abnormal return, nor is the market value of equity. As with the conversionforcing sample, the correlation between REDUCE and the stock price reaction is negative, which suggests a giveaway effect.

Table 7, Panel C, reports the regression results for the long-term sample. The coefficient on RSD is significant and positive, which is consistent with the correlation results reported in Panel A but contrary to our expectations. Neither the market-to-book ratio nor firm size exhibits a significant coefficient. The coefficient on REDUCE is significant and negative, as is its correlation with the stock price reaction.

For both the conversion-forcing and the long-term samples, the regression and correlation results suggest a giveaway effect: The greater the percent reduction in the warrant exercise price, the more negative is the stock price reaction. Our findings also contain an unexplained relation in that for both samples, the residual standard deviation has a positive association with the stock price reaction.

\section{Long-run viability}

To assess the long-run viability of the sample firms, we track their failure rates and those of their control firms. Initially, we follow Schultz (1993a) and count the number of firms delisted one, two, and three years after the announcement. For the conversion-forcing firms we find that nine firms are delisted within one year of the announcement, 11 more firms are delisted within two years, and an additional nine firms are delisted within three years of the announcement. For their control firms we find that eight firms are delisted within one year of the announcement, 14 more firms are delisted within two years, and an additional nine firms are delisted within three years. The number of delistings in the conversion-forcing sample is not significantly different from the number of delistings observed in their control firms. As noted earlier, the conversion-forcing firms are significantly younger than their control firms. We would thus expect them to fail at a higher rate, ceteris paribus. The finding that they fail at a rate no higher than the controls is evidence of their long-run viability. We infer that the capital received from the warrant exercise is typically invested in profitable projects. 
For the long-term sample we find that ten firms are delisted within one year of the announcement, nine more firms are delisted within two years, and an additional four firms are delisted within three years of the announcement. For their control firms we find that eight firms are delisted within one year of the announcement, seven more firms are delisted within two years, and an additional 12 firms are delisted within three years. The number of delistings is not significantly different for the long-term sample relative to that of their controls. This finding supports the conjecture that a permanent reduction of the warrant exercise price realigns managerial incentives.

Shumway and Warther (1999) suggest that negative performance is associated primarily with CRSP delisting codes 400 and 500-588. Using these codes we find that six of the conversion-forcing firms are delisted within one year of the announcement, ten firms are delisted within two years, and seven of the firms are delisted within three years. The control firms have seven, 12, and eight delistings over the same intervals, again suggesting that the conversionforcing firms do not fail at a higher rate than the control firms. For the longterm sample, seven, eight, and four firms are delisted over three years. Their control sample shows six, five, and nine delistings over the three years following the announcement.

We calculate the unadjusted returns of the sample and control firms over the three-year period starting the month after the announcement. Using all available observations, the firms in the conversion-forcing sample earn an average cumulative three-year return of $40.65 \%$. Their control firms exhibit an average cumulative three-year return of $-3.14 \%$. The difference in performance is significant at the $1 \%$ level. For the long-term reductions, the average cumulative three-year return is $27.53 \%$. Their control firms earn $-7.00 \%$. The difference between the two is significant at the $1 \%$ level.

As we move further away from the announcement, the use of all available observations diminishes the sample size because of delistings. As an alternative measure of long-run performance, we also examine only those companies for which we have 36 months of data. This procedure reduces the sample size to 75 for the conversion-forcing sample and 45 for the long-term sample. The conversion-forcing firms have an average three-year cumulative return of $69.02 \%$, while their controls return $21.95 \%$. The difference is significant at the $1 \%$ level. The long-term reduction firms have an average three-year cumulative return of $60.55 \%$, while their controls earn $11.46 \%$ over the same interval. The difference in performance is significant at the $1 \%$ level.

For the conversion-forcing sample, the long-run performance measures reinforce the conclusion that the proceeds from the warrant exercise are not squandered. For the long-term sample, the long-run performance measures support the notion that the reduction of warrant exercise price restores managerial incentives. 


\section{Summary and conclusions}

We examine announcements of discretionary reductions in warrant exercise prices. For firms that announce a reduction in warrant exercise price, the reductions are either conversion-forcing or long-term reductions. Conversionforcing reductions induce warrantholders to exercise, but long-term reductions do not.

Although the motivations for the two types of reductions might be different, the firms that constitute the samples are similar. They are typically small and young. They derive much of their value from growth opportunities, and have poor operating performance prior to the reduction in exercise price.

For the conversion-forcing sample, we find an average day 0 abnormal return of $-1.53 \%$, of which $-0.30 \%$ is a wealth transfer to warrantholders. The remainder represents the net effect of the positive cost savings associated with this equity-raising method and the negative SEO announcement effect. The conversion-forcing firms do not fail at a higher rate than their control firms, and outperform the control firms over a three-year period following the announcement. This finding suggests that management invests the money raised from warrant exercise in profitable projects. We interpret the results as consistent with warrants as efficient contracts that facilitate the equity financing process for these firms.

For the long-term sample, we find an average day 0 abnormal return of $-1.15 \%$, of which $-0.36 \%$ is a wealth transfer to warrantholders. The remainder represents the net effect of the negative information implied by the announcement and the positive impact of the restoration of managerial incentives. The long-term firms do not fail at a higher rate than their control firms, and outperform the control firms over a three-year period following the announcement. The results support an "incentive realignment" explanation for the reduction of exercise price.

The evidence suggests that there are no material conflicts between shareholders and warrantholders, and that the costs of potential shareholder/manager agency conflicts that arise from the managerial option to reduce warrant exercise price are outweighed by the benefits of managerial flexibility. We interpret the results as consistent with warrants as efficient contracts that facilitate the equity financing process for these firms at a time when other avenues of financing are either not available or are more expensive.

\section{References}

Acharya, V., John, K., Sundaram, R., 2000. On the optimality of resetting executive stock options. Journal of Financial Economics 57, 65-101.

Altinkiliç, O., Hansen, R., 2000. Are there economies of scale in underwriting fees? Evidence of rising external financing costs. Review of Financial Studies 13, 191-218. 
Anderson, C., 1999. Financial contracting under extreme uncertainty: an analysis of Brazilian corporate debentures. Journal of Financial Economics 51, 45-84.

Asquith, P., Mullins, D., 1986. Equity issues and offering dilution. Journal of Financial Economics $15,61-89$.

Barclay, M., Smith, C., 1995a. The maturity structure of corporate debt. Journal of Finance 50, 609-631.

Barclay, M., Smith, C., 1995b. The priority structure of corporate debt. Journal of Finance 50, 899-917.

Boehmer, E., Musumeci, J., Poulsen, A., 1991. Event-study methodology under conditions of event-induced variance. Journal of Financial Economics 30, 253-272.

Carey, M., Post, M., Sharpe, S., 1998. Does corporate lending by banks and finance companies differ? Evidence on specialization in private debt contracting. Journal of Finance 53, 845-878.

Easterbrook, F., 1984. Two agency-cost explanations of dividends. American Economic Review 74, 650-659.

Guedes, J., Opler, T., 1996. The determinants of the maturity of new corporate debt issues. Journal of Finance 51, 1809-1833.

Hall, B., Murphy, K., 2000. Optimal exercise prices for executive stock options. American Economic Review 90, 209-214.

Howe, J., Wei, P., 1993. The valuation effects of warrant extensions. Journal of Finance 48, 305314.

Jensen, M., 1986. The agency cost of free cash flow, corporate finance, and takeovers. American Economic Review 76, 323-329.

Johnson, S., 1997. An empirical analysis of the determinants of corporate debt ownership structure. Journal of Financial and Quantitative Analysis 32, 47-69.

Kahan, M., Yermack, D., 1998. Investment opportunities and the design of debt securities. Journal of Law, Economics and Organization 14, 136-151.

Krishnaswami, S., Spindt, P., Subramaniam, V., 1999. Information asymmetry, monitoring, and the placement structure of corporate debt. Journal of Financial Economics 51, 407-434.

Mayers, D., 1998. Why firms issue convertible bonds: the matching of financial and real options. Journal of Financial Economics 47, 83-102.

Mikkelson, W., Partch, M., 1986. Valuation effects of security offerings and the issuance process. Journal of Financial Economics 15, 31-60.

Miller, M., Rock, K., 1985. Dividend policy under asymmetric information. Journal of Finance 40, 1031-1052.

Myers, S., Majluf, N., 1984. Corporate financing and investment decisions when firms have information that investors do not have. Journal of Financial Economics 13, 178-222.

Sahlman, W., 1990. The structure and governance of venture capital organizations. Journal of Financial Economics 27, 473-524.

Schultz, P., 1993a. Unit initial public offerings: a form of staged financing. Journal of Financial Economics 34, 199-229.

Schultz, P., 1993b. Calls of warrants: timing and market reaction. Journal of Finance 48, 681-696.

Shumway, T., Warther, V., 1999. The delisting bias in CRSP's Nasdaq data and its implications for the size effect. Journal of Finance 54, 2361-2379.

Smith, C., 1977. Alternative methods for raising capital: rights versus underwritten offerings. Journal of Financial Economics 5, 273-307.

Smith, C., 1986. Investment banking and the capital acquisition process. Journal of Financial Economics 15, 3-29.

Smith, C., Watts, R., 1992. The investment opportunity set and corporate financing, dividend, and compensation policies. Journal of Financial Economics 32, 263-292.

Stein, J., 1992. Convertible bonds as backdoor equity financing. Journal of Financial Economics $32,3-21$. 